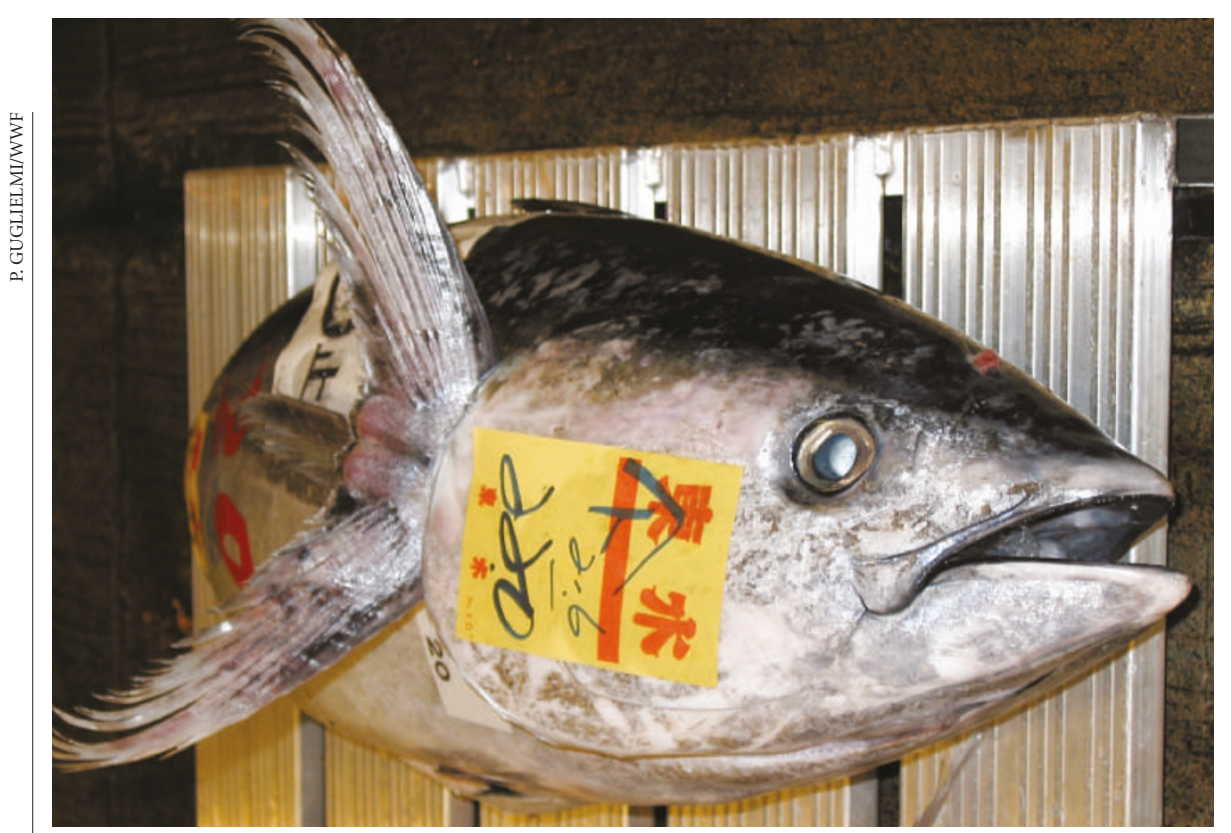

High stakes: conservationists fear that overfishing may destroy the bluefin tuna population.

\title{
Plans to track tuna canned amid claims of cash shortfall
}

Rex Dalton, New Orleans

A research programme to investigate populations of Atlantic bluefin tuna has been shelved by the international commission charged with conserving the fish.

The first phase of the project failed to win approval at the meeting of the International Commission for the Conservation of Atlantic Tunas (ICCAT) in New Orleans, which ended on 21 November.

ICCAT officials say that its $€ 2$-million (US\$2.6-million) annual budget cannot accommodate the $€ 250,000$ initial cost of the research programme. But scientists and environmental groups who back the programme claim it was scuppered because some ICCAT parties don't want to hear the likely results of the research.

In particular, they charge, European government officials are worried that if stronger links are established between the bluefin populations on the two sides of the Atlantic Ocean, there would be greater pressure on them to cut European tuna fishing.

Some say that ICCAT's failure to pursue the research will hasten the collapse of the bluefin population. "It's a nightmare," says marine biologist Paolo Guglielmi, who heads the Mediterranean fisheries programme for environmental group the WWF in Rome. "Everybody sees the danger approaching, but no one can agree on how to escape it."

"What the commission is doing is very short-sighted," agrees John Graves, a fisheries geneticist at the College of William and Mary in Virginia, who chaired a committee of advisers to the US delegation to the meeting. "Ideally, the management of the fishery should be based on science. That is not happening."
European Union (EU) representatives at the meeting argued that ICCAT couldn't afford the research project. John Spencer, head of the EU delegation, declined to be interviewed for this article. In contrast, US officials argued unsuccessfully in favour of the programme.

ICCAT currently allows an annual quota for the eastern Atlantic of 32,000 tonnes of bluefin, but even its officials acknowledge that the actual catch is probably more than 40,000 tonnes. Fishermen in the Mediterranean say that they would probably benefit from more research and tighter quotas on their catches. But Graves claims that EU officials don't care what happens "because when the bluefin population plummets, they will already be gone".

The research proposal was developed in May 2003 by an international panel appointed by ICCAT. It would aim to develop a better understanding of the bluefin's life cycle, and to determine if there really are two separate stocks - one in the east spawning in the Mediterranean, and one in the west Atlantic spawning in the Gulf of Mexico.

The fish are currently managed as two separate stocks, and fishing in the west Atlantic is far more tightly restricted, with an annual quota of just 2,700 tonnes. But studies of electronically tagged bluefin indicate that some fish cross the ocean, and many marine biologists think that the population in American waters is being depleted by European fishing.

Although the scientists were unsuccessful in New Orleans, Masanori Miyahara, a Japanese official and chairman of ICCAT, said he was optimistic that a research programme might be approved when the commission holds its next meeting in Japan next April.

\section{Nuclear agreement paves way for fuel recycling in Japan}

Ichiko Fuyuno, Tokyo

Japan's bid to recycle nuclear fuel at home came closer to reality this month, with the announcement that a massive, US\$27-billion recycling plant is set to begin trial runs early next year.

On 22 November, local government officials in northern Aomori, the prefecture where the plant is being built, said that they had signed a safety agreement with its operator, Japan Nuclear Fuel Limited, to allow the tests to go ahead.

The decision had been eagerly awaited by Japanese power companies, who see recycling as essential for the long-term future of the country's nuclear-power industry. Japan currently gets about onethird of its electricity from nuclear power.

Aomori had hesitated to approve the tests because of safety problems involving faulty welds and leaks of radioactive water from the plant's spentfuel storage pool.

But earlier in November, Japan's Atomic Energy Commission endorsed the recycling plan, and Aomori's licensing decision opens the way for the plant to begin operating. The prefecture's decision is "remarkably important", says Yohsaku Fuji, chairman of the Federation of Electric Power Companies of Japan.

The trial runs will last for a year and use depleted uranium, a by-product of nuclear-fuel processing in Japan, instead of spent nuclear fuel. If it is successful, the plant could start reprocessing spent fuel in 2006.

Japanese power companies plan to burn the reprocessed fuel, which contains plutonium as well as uranium, in their existing nuclear-power stations. The country eventually hopes to use the fuel in 'fast-breeder' reactors, although their development has been stalled since an accident at a prototype reactor in 1995.

Japan's reprocessing plans have been heavily criticized for their high costs and because they produce material that could theoretically be used in nuclear weapons.

In addition, the plans do not address how Japan should dispose of an estimated 200 tonnes of spent nuclear fuel a year that the recycling plant can't accommodate. Japan has said this will be addressed in 2010. "The government has put off the disposal problem, which would affect Japan's entire nuclear-power policies," says Hajimu Yamana, a nuclearenergy professor at Kyoto University. 